\title{
Rewriting the Women Enmity Lore: New Voices in Autobiographical Narratives
}

\author{
Anthonia Makwemoisa Yakubu*
}

Department of Languages, National Open University of Nigeria, Nigeria

Corresponding Author: Anthonia Makwemoisa Yakubu, E-mail: ayakubu@noun.edu.ng

\section{ARTICLE INFO}

Article history

Received: April 09, 2018

Accepted: July 10, 2018

Published: August 31, 2018

Volume: 9 Issue: 4

Advance access: July 2018

Conflicts of interest: None

Funding: None

Key words:

Women,

Patriarchy,

Folktales,

Nigeria,

Gender,

Autobiography

\begin{abstract}
Many women were socially conditioned as children to believe that gender operates on a superiority/inferiority axis - the male has been naturally created to be in charge and to take dominion of all living and non-living things including plants, animals, fishes, birds, children, and women. For the women, they are to be submissive to the biological order of things which patriarchy has worked hard to institutionalise. One of the means patriarchy has adopted to sustain this belief is the divide and rule tactic, where women are taught to believe that they cannot work together, cannot love one another and cannot support one another because they do not like themselves. This belief is propagated through folklore, especially in co-wife rivalry tales. Another common instance is the raging 'war' between mothers-in-law and daughters-in-law. This paper will analyse the common myth that women are their own worst enemies through selected Nigerian folktales, and in the second part, will analyse contemporary Nigerian women's autobiographies, with particular emphasis on the 3-volume biographical compendium, Women of Valour, and how these women negated this erroneous belief in their narratives. One of the findings of this paper is that women's autobiographies have significantly disabuse many of these patriarchal myths about women, thereby rewriting and re-narrating women's life histories. Another finding is that many of the women featured in the biography used the medium as a platform to voice themselves into being, thereby empowering themselves through the narration of their life stories.
\end{abstract}

\section{INTRODUCTION}

The relationship between man and women in many patriarchal societies, including Nigeria, has generally been 'peaceful' because of a number of seemingly harmless measures, strategies and factors that have been put in place to ensure the continuity of the society. Societies are peopled by leaders and followers, rulers and servants, parents and children, teachers and students, governments and people, the elect and the electorates, men and women. It is the last category that make up the earlier mentioned category and that we all fit into. The dichotomy seen in all human relationships operates on a power axis: the ruler and the ruled, the leader and the led. In the beginning therefore, men and women were made to believe, through the propagation of certain myths and beliefs, that men or the male sex, have been mandated to take charge and rule the world. Further myths were created to maintain and sustain this belief, and to quell dissenting voices from the female sex. Walby (1990) identifies six structures of the patriarchal system, which have been deliberately erected for the sustainability of the system. These are the patriarchal mode of production; patriarchal stance in paid work; patriarchal attitude in politics; male violence; patriarchal cultural institutions; and patriarchal relation in sexuality. These mea- sures and strategies revolve around voice/voicelessness/ silence. Women were therefore silenced into subjugation, fear, backlash, and powerlessness. It is necessary to look at how this process were and are enacted to achieve this objective.

Okpewho (1983:19) describes myth as the quality of fancy which informs the creative or configurative power of the human mind in varying degrees of intensity". Myths are creatively constructed to entrench and propagate particular beliefs, biases, and fears. This is reflected in the myths the contemporary world is enmeshed in: political myths (of Marxism, democracy, socialism, independence, post-colonialism, liberalism, capitalism, and all sorts of "isms"); economic myths (of first, second and third worlds, globalisation, free markets, equal employment opportunities, etc.); and other types of myths in the various spheres of human endeavours. Myths are transmitted orally and textually and can be manipulated to fit into what is or is expected to be (Anyidoho, 1986; Kolawole, 1998). Myths were held in high regards because of the sacredness they were cloaked in they were believed to be divinely inspired and handed down through the gods from one generation to the other. They were also used to explain certain natural phenomena that could not be logically explained then. For example, night and day, 
the origin of twins, rainbows, and the so many 'whys' that needed logical answers.

The most pervasive of these myths are the ones about women. Over the centuries, some perceptions about women have just refused to be wiped out, in spite of the gallant strides many women, in Africa for example, have made since pre-colonial times (Asante, 1987; Chukwukere, 1995; Ogundipe-Leslie, 2007). Many of such perceptions came into being through myths. New myths are constantly being created to legalise the existing ones and to sustain gender relations, which operate on a positive/negative dichotomy (Ezeigbo, 1993:93). This dichotomy serves a dual purpose: they inculcate in women a strong sense of inferiority in comparison with the male sex. Men draw upon the myths and the subsequent inferiority of women to justify their own sense of leadership in all spheres of life, even in areas pertaining to women's body, health, relationships, etc.

The anonymity of the sources of myths facilitates its internalisation, especially as it is often ascribed to have originated from one god or the other. They are powerful tools for transmitting and enforcing moral codes and discipline. They are also employed in explaining and in legitimising oppression. As a result of the internalisation of these myths over a long period, women come to see their inferior status in the social, political and economic realms as "natural" and somewhat irreversible. Gendered myths have thus contributed largely to violence against women, women's inheritance problems, women's poverty, and institutionalised silencing.

An aim of this paper is to review some of the mythical contexts that encourage the distrust between women in a patriarchal society in Nigeria, and how the actual life histories of these women negate many of these promoted myths that perpetuate women's 'hatred' of one another. It is the goal of this paper to put many of this gendered myths and views, particularly about women, in a proper context, and illuminate the life experiences of women in their own words. Through the 'herstory' of these women, their place in the development of their country is further highlighted.

\section{Folklore and the Disunity Among Women}

To maintain the status quo, patriarchy adopts the divide and rule tactic by propagating a belief that has over the years become embedded in people's consciousness - that women are their own worst enemies. This belief propagates that women cannot find a common ground to harness their potentials and work together for their good and the good of all. Conclusively then, women are encouraged to transfer and devote their strengths and capabilities to the men. The touted belief that women naturally distrust themselves and cannot be trusted anyway is cemented into people's consciousness from childhood through folklore, particularly folktales, seen in storytelling session in communal compounds, classrooms, textbooks, storybooks, print and electronic media.

Folklore is vital to a community's existence and sustainability. It is a body of cultural beliefs adopted for conditioning the minds of people to uphold the community's moral codes. The type of people we are socialised to become emanated from the particular folklore we are raised by; social institutions like schools and churches have their foundations laid on folkloric beliefs and attitudes. Generations after generations, certain folkloric types are discarded for new ones, and some aspects are modified to reflect the changing times. As a society is always in motion and fluidity, so also is its folklore. However, gender beliefs and attitudes about girls and women have generally remained negative in relation to men because of the relevance of folkloric practices to the sustainability of patriarchal societies (Baquedano-Lopez, 2001). Folklore is made up of the myths, proverbs, folktale, songs, chants, rituals, dance, etc. of a people. However, in this paper, we shall pay particular attention to the folktale.

Folktales are used to condition the audience, especially children, to the community's way of life. Through the entertaining qualities in folktales, children begin to understand and accept the society they live in and their fear of the unknown gradually recedes to a manageable level. For women, stories are narrated to encourage bonding, console one's pains in the face of injustice, strengthen one's survival instinct, teach and inform, offer therapeutic healing, amongst other advantages. Folktales present a viable means to inculcate in children gender fears and biases about each sex. Whether the narrator is male or female, one thing is uppermost in his or her mind: to transmit the society's beliefs and expectations to the next generation, so that the particular community will continue to exist. Since the community is based on a gender dichotomy that favours one sex over the other, folktales are narrated to maintain the status quo. Under the banner of entertainment in songs, poetry and laughter, the lesson is instilled in the minds of the audience.

Folktales that are narrated to show the place and position of women in the society are usually negative in nature. They present women as weak, untrustworthy, wicked, calculating, petty, properties and commodities, and subservient to the male sex. Most of the folkloric types of these kinds of stories are the common co-wife rivalry tales and the mother-in-law/ daughter-in-law tales. Patriarchy has over the centuries adopted the popular adage that "a house divided against itself cannot stand", as a strategy to sustain patriarchy. Women are conditioned not to trust themselves, to believe the worst of the other, and to always see the other woman as a "competitor". They express this distrust through acts of violence intended to subdue the other woman into silence. Interestingly, women take on the position of the man in these instances and perpetuate the same violence they suffer from the hands of men, onto fellow women.

The meting out of violence on women by women, especially through the instrumentality of class, ethnicity, race, and religion, challenges simplistic analyses about "male violence" and raises important questions about the nature of patriarchy, and women's active participation in it. More specifically, it suggests that in certain contexts, women have vested interests in these forms of mutilation. Co-wife rivalry, for example, implies that woman abuses are rooted in social relations of the society, and that these favour men and the dominant women (Mama, 1989). The social machinery is lubricated by the distrust amongst women. As long as women cannot come together and work for their common good, patriarchy would continue to thrive. 


\section{Thematic analysis of selected folktales}

The body of Nigerian folktales is filled with co-wife rivalry tales of at least two women creatively putting measures in place to 'eliminate' the other. They vie for the man's affection and attention in the face of meagre resources. Through this story type, women are portrayed as petty and receptacles of the green-eyed monster, jealousy.

And what about the man, the source of the discord? His seeming powerlessness conceals his complicity in and support of the strained relationship between or among the women in his lives. The distrust between his wives further serve to strengthen his hold on them and their transfer of allegiance to him. His wives' disunity sustains patriarchy. The major advantage proponents of polygamy brandish is economical: it provides many hands of labour on the man's farms, which translates to a rich harvest and more food on the table. But it does not explain the commodifying of women as properties and means of labour.

A cursory look at most of the folktales that have women against women as their theme shows that, most times, the conflict occurs in a matrimonial setting. What this infers is that the women in conflict are, most times, co-wives. However, whether they are co-wives or not, there is always a centre of attraction, whose presence provokes a conflict. The centre of attraction is the man. His wives are either competing for his attention or reacting to his selfishness and ingratitude, as seen in his taking on more wives, or lavishing his time, money, and attention on the new wife/concubine. The result of the angling, scheming, verbal and physical assaults of these women - co-wives, mothers-in-law, girlfriends, stepmothers, stepdaughters - are, in most cases, often disastrous.

Our first story, "Igbako Orogun" (co-wife ladle), is from the Yoruba. A man is married to two wives. A seemingly peaceful co-existence prevails between the two. Culturally, the senior wife expects the junior wife to serve her by fulfilling any domestic task she may want the junior one to carry out for her. In the course of carrying out one of these errands, she gets into trouble. She is washing the plates, cutlery, and kitchen utensils of the senior wife by the stream, when a strong current carries away a ladle. Weeping profusely because of the trouble that awaits her if she does not come back with the ladle, she jumps into the water and swims after it. However, fortune smiles on her through the appearance of an old man who repays her for her good naturedness. She returns not only with the ladle, but also with immense wealth. Envy rears its ugly head in the senior wife's heart, and she decides to re-enact the action of her junior wife by the stream. But hers is a different story; her impatience to acquire as much fortune, if not more than her co-wife's, made her blind to the right gourds she should have plucked. She dies as a result of the contact with the evil contents in the gourds.

The second part of this tale is not of much interest to us. Of interest to us is the first part which reflects the title of this section. A peaceful relationship exists between the cowives because the junior wife respects her social position. Even though it is not stated in the body of the tale, the senior wife oppresses the junior one so much that the latter went into a panic when the torrent carried the former's ladle away.
Though physical assault is ruled out here because the junior wife shows deference to her co-wife, we can surmise that the junior wife has been a victim of a series of psychological assaults which reached its peak when her co-wife's ladle got missing under her care. The seemingly peaceful co-existence hinges on a senior/junior dichotomy; peace continues to thrive in an atmosphere of fear. It is because of the fear of the unknown, the fear of not knowing how far the senior wife could go to inflict pain that makes the junior wife jump into the stream to fetch her co-wife's ladle. She would rather drown from going after her co-wife's ladle than go back home without it. The propelling force is the fear of her cowife's anger and the punishment she could mete out to her. The stream could not put out this fire of fear, but only propels her closer to the ladle, and then to her good fortune.

This co-wife folktale transmit a number of beliefs into the audience's minds chief among which is that women are petty and naturally prone to jealousy and because of this, they cannot work together for the successful management of their husband and the home. However, the disunity between the wives does not bother the man too much, as long as his wives continue to fulfil their marital responsibilities to him. If the situation between the wives gets too bad, patriarchal society 'eliminates' the bad woman through public shame and ridicule, and in some instances, death.

Women, like men, maintain long lasting friendships with one another. They look out for the other's wellbeing and help to take care of each other's children when needs arise. They carry out these acts joyfully, knowing that the help they render to the other would be reciprocated sometimes later. However, this picture of serenity is shattered when a man is involved. When a man stamps his ego on women's lives by marrying more than one wife, each woman no longer sees the other as a sister, but as a contender for the larger share of affection from the man at the centre.

The Bini tale "Imaguero's Beautiful Eyes" clearly demonstrates this. Imaguero has beautiful eyes and her husband and many people like her because of this. In those charming eyes lies not only beauty but also the ability to do things and carry out house chores effortlessly. Her co-wife, Atiti, yearns to have these qualities; she wants the husband to love her deeply too. To achieve her goal, she decides to eliminate her rival from the scene, and acquire her eyes. Though she kills her co-wife and removes her (the co-wife's) eyes to place over hers, the husband never loves her more, and neither does her efficiency of house chores improve. Her mission thus fails. This tale illustrates a woman's unwillingness to share her husband, her prized possession, the result being the destruction of her fellow woman.

Some scholars (Ogundipe-Leslie, 1985; Oyewunmi, 1997; 2004) have argued that the cry against polygamy is a western idea that does not reflect the African reality. They cite examples to show that polygamy is beneficial to the woman as, among other advantages, it saves her from the burden of continuous house chores. More than one wife means that house chores can be shared, and the higher the position of the wife on the hierarchy, the lesser household chores she performs. They also argue that apart from the complementarity of roles of the sexes, the relationship be- 
tween the sexes was hardly often a romantic love story. The absence of emotional dependence of the sexes on each other means that women had more time to be productive and successful at their various businesses.

However, co-wife folktales show that just like men, women do not want to share the intimate relationship they have with their husbands with other women. Such a condition creates feelings of inadequacy and worthlessness because of the time-consuming competitiveness and jealousy it breeds in the parties concerned.

\section{Female autobiographies and the narratives of self representation}

The negative portrayal of women in many folktales, especially co-wife tales, has had far reaching consequences for the development of women in the contemporary world. Some of these effects, magnified by the patriarchal historical events of the slave trade, capitalism and globalisation, have prevented women from access to education, power, finance, opportunities, personal development, among others. These are all geared towards one objective: to keep women silent, echoing the age-long patriarchal myth that women should be seen, not heard.

But contemporary women, like some of their traditional counterparts, have worked hard to create spaces of empowerment for themselves, even in some contexts that have been quite stifling to their personal development. While it may be argued in some quarters that folktales are no longer relevant to the contemporary world, and so the issue of women against women no longer exists, reality thinks differently. The negative images many traditional folktales promoted about women generally are still with us; they have been adopted to reflect the modern world we are in. These images are still propagated in music, novels, textbooks for primary and secondary schools, and the electronic and print media is awashed with it.

The women against women narrative trope common in co-wife rivalry tales has in the contemporary world created another trope: mother-in-law versus daughter-in-law, so pervasive in modern lore about women being their own worst enemies. While it was rare to find a folktale of that nature in traditional lore, may be because a man lived with his wives and children in a separate compound, far from his parents and siblings, thereby limiting physical closeness and the friction it could have generated, it could also be that in many traditional and even contemporary beliefs about marriage, when a woman marries a man, she marries his family as well. The Western practice of individuality is at variance with the communal way of life of many African communities, though in modern day Africa, globalisation has eroded many of these values and practice.

While modernity has changed to some extent the communal way of life of many Africans, it has not changed its posture and beliefs about women, in spite of the many gallant strides women have made to personal, local, national and international development. So, the modern woman has to contend with the women against women myth in her relationship with her female in-laws, particularly her mother-in- law. It is true that in many Nigerian widowhood rites, fellow women are at the forefront of ensuring that certain harmful practices are carried out on the poor widow to verify her innocence in the death of her husband, but they do this in light of their being the custodians of culture, in the misplaced belief that they are contributors to the sustainability of their communal existence and meaning. It is in this same light that women rally round one of their own when her husband has been unjust to her, as done in some Igbo communities in Nigeria. If a woman has been unjustly treated by a husband and the claim verified, other women marched to the victim's house, and calls out her husband, publicly ridiculing him (Ezeigbo, 1998).

So, how has the contemporary woman, living in a still patriarchal world been able to contend with the negative myths that want to impede her personal growth and development? She creates narratives of self-representation, and in doing this, she gains healing, empowerment and advancement that ultimately lead to the development of the community she is in. Through writing, women revoked the negative stereotypes for new values and beliefs that presented them just as they are: human beings interested in working together with the male folk for a peaceful, equitable and just world.

Even though women played significant roles alongside the men during the nationalist struggles for Nigeria's independence, they were not allowed to participate in governance at the attainment of the country's independence. Many of the newspapers founded by male nationalists were adopted as platforms to re-inscribe the place of women in the society. For example, Herbert Macaulay used his newspaper, Lagos Daily News, to advocate for polygamy and traditional medicine (McIntosh, 2010: 62). A columnist on Nnamdi Azikwe's newspaper, West African Pilot, advised women to stay at home and look after their husbands and children, as working in the formal sector could break up their home (McIntosh, 2010: 78). However, Nigerian women nationalists used these same newspapers to air their views, and over time, they gained a large followership of readers. For instance, Mrs Adeyemi Adekogbe published many articles on the pages of the Nigerian Tribune, the West African Pilot, and the Southern Nigerian Defender to discuss the women's struggles. She also established the Nigeria's Women's Movement in December 1952, "to champion the cause of women" (Little, 1975). As women got more involved in nationalist struggles, they also challenged the existing status quo in gender relations.

The circumstances and challenges of colonial and post-colonial Nigeria notwithstanding, a growing number of women writers started to appear on the all-male literary space. The first was Flora Nwapa, with her novel, Efuru, published in 1966, followed in 1979 by Buchi Emecheta's The Joys of Motherhood. Their writings address social expectations that have been used to castigate women, particularly infertility and lack of male children, polygamy and spinsterhood. Some of these novels and plays that call for better gender relations include Emechata's Joys of Motherhood and Second Class Citizen; Onwueme's The Reign of Wazobia and Shakara: Dance Hall Queen; Adimora-Ezeigbo's The Last of the Strong Ones, House of Symbols, and 
Children of the Eagle; Okoye's Behind The Clouds and Men Without Ears; Atta's Everything Good Will Come; and Adichie's Purple Hibiscus and Americanah.

While women have been able to make their voices heard and tell their own stories through works of fiction and poetry, they took a bolder step and started to write directly about themselves. Gone were the days when aspects of the autobiographical were infused into works of fiction, perhaps to prevent the all too knowing male gaze to strip them from the newly self-worth they had gained through writing. Women now write about themselves, barring it for all to see. Through writing directly about themselves and their experiences, they debunk many of the myths people have been conditioned with, especially the mother-in-law/daughter-in-law rivalry.

Criticism against the biographical genre has been that it is highly subjective, a means by which the subject gives untrue and incorrect information in order to make himself or herself appear to be what $\mathrm{s} / \mathrm{he}$ is not. It has also been seen as a platform to malign one's perceived enemies. While the biographies of men have received some form of attention based on the issues raised, biographies by women have most often been unduly criticised, not based on issues arising from the narration in the publications, but based on personal 'vendetta' - critics have focused more on the person than on the writing. For example, the $19^{\text {th }}$ century biographies, particularly those of Catherine Cappe and Elizabeth Cady Stanton, Memoirs and Eighty Years and More: Reminiscences, 1815 1897 have been criticised as being too Victorian, too insistent on the women suffrage movement, and the language too flowery. However, in the autobiographical genre, women have spoken with candour and used it as a creative platform to participate in private/public discourse, to carve a niche for themselves, to attain healing and personal growth, and to reclaim for themselves authority over the text, be it spoken or written. For Nigerian women particularly, who have been conditioned to be silent partners alongside the men, writing and writing about oneself have provided an exhilarating exercise to write themselves into history.

\section{The women of valour biographical compendium}

The average Nigerian woman is discriminated against because she does not have the prerequisite education. She does not know her bearings and in most cases, dependent in terms of income and decision making.

- Mahdi, p.349, WOV, vol. 2

Women of Valour is a three-volume biographical compendium of 56 Nigerian women from the different geographical zones of the country. Their careers/professions cut across business, education, politics, law, public service, health, the media, finance, private sector, sports, entertainment, etc. It was conceived because of the observation that female children had very far, almost non-existent role models from the growing female public figures whose lives they have read about and can look up to. The publications are patterned according to the career development/social rank/ages of the women. From the life stories of the 56 featured female elites, some core shared characteristics are observed and would be discussed.
The biographical compendium is in three volumes that profile the lives of Nigerian women who have been very active career-wise. This is to debunk the myth that the average Nigerian woman is unintelligent, cannot earn good income, and is dependent on the men in her life to make critical decisions on her behalf. The compendium negated many of these myths through the life stories of these women, as they opened up on the challenges they experience as women in the public eye. The size of the compendium - in three volumes- not only attests to the large amount of women who were ready to voice and talk about their life histories, but it also confirms the view that even though women are not a homogenous group, their experiences in a patriarchal society are similar. Volume 1 one of the biography, Icons of Excellence, documents the narratives of Nigerian women who have risen to the top echelon of their career. Volume 2, Models of Achievement, features women who are reached a high level of careers and manage large corporations, while volume 3, Jewels of the Future, chronicles the voices of young and vibrant Nigerian women who have started to rise on the career ladder. The next section will discuss the recurring subjects raised by the women and some of the findings from the analysis of their narratives.

All of the 56 women featured in the biographical compendium had formal education. The colonial government established secondary schools for both male and female students, and then send on scholarships to universities abroad male students who were interested in getting university education. Most often female students do not go beyond secondary or vocational schools. However, for many of these women, they had university degrees from schools in the United Kingdom especially. They are enlightened and strove to acquire professional degrees apart from the one they had earned.

Closely related with the quest for a university degree is the issue of marriage. While many of the women from the south east and western states never had any challenges in terms of who and when to marry, this was not the case for the women from the northern part of the country. They had to fight a cultural practice that expect them to marry as from the age of twelve. For Haliatu Abdu(WOV, ) and Florence Aya (WOV) they had to acquiesce to societal demand, got married, and then continued their formal education after settling down into the marriage. But for Sani, who was living with her uncle while in secondary school, she had to take a spur of the moment decision when she came home after school to meet a group of women ready to bundle her to her betrothed husband. Her scream and pleading with her uncle saved the day for her and delayed her being given to a much older man in marriage for many years.

The stories of these women also negate the common belief that women in the northen parts of Nigeria do not attend schools. The story of Haliatu Abdu and seven other Hausa women in the compendium confirms the reality that many Hausa women attend schools, even if their parents/guardians are not educated. The high number of girls from the northern Nigeria that attend secondary school can be deduced from the 276 girls that were abducted from a seconadary school in Chibok, Bornu State. Many of them go to tertiary institutions after their secondary schools. 
However, for women like Sadatu Shehu Mahdi, and Hauwa Ibrahim, they deviated from the cultural norm as they got married after their university education, and to the men of their choice. These two women and the others were able to carve out empowering spaces for themselves through the attainment of good education. Added to this factor was their being brought up by enlightened parents/guardians and getting married to equally enlightened husbands.

One cannot talk about marriage without bringing in the issue of spinsterhood - women who are yet to settle down in marriage due to their being too busy or their yet to meet a man who is worthy of their time and attention. Aniagolu (WOV 3, p. 74) talks about the overt and covert discrimination against single women, who are always viewved as prostitutes whenever they attend a fuction in a hotel alone.

Work challenges present women with opportunities to affirm themselves, be creative and build a team of men and women who are willing to with them. A large chunk of the challenges relted to work is on stereotypical beliefs and attitudes from men and women who do not believe they deserve to be at the top. But with much wisdom, firmness and streng$\mathrm{ht}$, these women have maintained a stance that is respected by all. But for the politicians among these women, they have to constantly reassess themselves and situations in order not to be pushed over.

In all of these challenges, these women talk of a network of family and friends that they relied on in order to be able to create and maintain a balnce between the running of their homes and offices. Among this network are relatives, husbands and mothers-in-law. This thus negates the patriarchal belief that women cannot trust one another. How could women have coped with the high demands of being working women if there were no other women to act as guidesand supports in the murky waters of a patriarchal world?

Some of the findings from their narratives include:

- The women acknowledge that women can be mean to one another due to petty jealousies, but they have provided a strong network of support and bonding to one another.

- That patriarchy has helped to keep women on their toes, as in relation to men, they are more thorough in carrying out their tasks.

- Society has been discriminating towards women, but women have created strategies to help surmount this.

- Marriage is not a do-or-die matter, and motherhood transcends one's biological children.

- Formal education is the key to economic power. And,

- Men as fathers carried out the invaluable role of giving them a good education, which has provided the background to their career success.

\section{CONCLUSION}

Before giving a summary of this paper, we shall give apt quotes some of the women gave in the course of narrating their stories:

Women are gifted. We manage homes and offices. Women manage everything around them, including husbands. Benson, p.303, WOV, volume 2.
I believe the acquisition of formal education is the best form of empowerment most women need. Economic empowerment usually comes with education. - Jaja, p. 279, WOV, volume 2 .

The first challenge I encountered was for people to accept that a woman is capable of handling the responsibility entrusted to her. - Sani, p.326, WOV, volume 2.

My greatest strength is my belief in myself. - Mahdi, p. 362, WOV, volume 2 .

Through the autobiographical genre, Nigerian women have documented their voices for posterity, debunking and negating the different gendered myths and beliefs that had held them down. There are new stories now and old ones are being recreated. The narrators are the women themselves, telling it as it is. More importantly, through the personal narratives of the women featured in the biographies, the myth that women are their own worst enemies is debunked. Even though a few of the women mentioned this phenomenon in their stories, majority of the women ascribe their present success and personal growth to the role played by fellow women in their lives. Therefore, women are not their own worst enemies. Patriarchal society has only conditioned everyone to believe so, but, thankfully, these women's stories have debunked the belief.

\section{REFERENCES}

Adichie, Chimamanda. (2003). Purple Hibiscus. North Carolina: Algonquin Books.

Adichie, Chimamanda. (2013). Americanah. New York: Alfred A. Knopf.

Anyidoho, Kofi. (1986). 'Mythmaker and Mythbreaker: the Oral Poet as Earwitness'. Juliet et al (Eds.) African Literature in its Social and Political Dimensions. Washington: Three Continents Press, Incorporated, 5-14.

Asante, M.K. (1987). The Afrocentric Idea. Philadelphia: Temple University Press.

Atta, Sefi. (2008). Everything Good Will Come. Massachusetts: Interlink Books.

Ba, Mariama. (1981). So Long a Letter. London: Heinemann.

Baquedano-Lopez, Patricia. (2001). 'Creating Social Identities through Doctrinal Narratives'. Issues in Applied Linguistics, 8(1), 27-45.

Chukukere, Grace (1995). Gender Voices and Choices: Redefining Woman in Contemporary

African Fiction. Enugu: Fourth Dimension Publishing Company Limited.

Emecheta, Buchi. (1979). The Joys of Motherhood. New York: George Braziller.

Emecheta, Buchi. (1983). Second Class Citizen. George Braziller.

Emecheta, Buchi. (1994). In the Ditch. London: Heinemann.

Ezeigbo, Theodora. (1993). 'The Enemy Within: Women against Women in Novels by Selected Nigerian Female Writers'. Ihafa - A Journal of African Studies, vol. 1, 7-13.

Ezeigbo, Theodora. (1998). The Last of the Strong Ones. Lagos: Vista Books.

Fisiak, Tomasz. (2011). Feminist Auto/biography as a Means of Empowering Women: A Case Study of Sylvia Plath's 
The Bell Jar and Janet Frame's Faces in the Water. Text Matters, Volume 1 Number 1, 183-197.

Jones, Ann Rosalind. (1985). "Inscribing Femininity: French Theories of the Feminine." Making a Difference: Feminist Literary Criticism. Ed. Gayle Green and Coppelia Khan. London: Routledge, 80-118.

Kolawole, Modupe. (1998). Gender Perceptions and Development in Africa. Lagos: Arrabon

Academic Press.

Li-Ching Sun. (2015). Linking Maternal Self-Efficacy, Mother- and Daughter-In-Law Relationship, and Role of Husband in Taiwanese Families. The Journal of International Management Studies, Volume 10 Number 1, February, 68-77.

Little, Kenneth. (1975). African Women in Towns: An Aspect of Africa's Social Revolution. Cambridge: Cambridge University Press.

McIntosh, Marjorie. (2010). Yoruba Women, Work, and Social Change. Ibadan: Bookcraft.

Maguraushe, Wonderand Treda Mukuhlani. (2014). Kupururudzira Muroora Songs in Muzvezve: Bride Welcoming Ceremony or Relegation of Women to the Subaltern? Nokoko, Institute of African Studies, Carleton University (Ottawa, Canada), (4), $41-65$.

Makwemoisa, Anthonia, ed. (2006). Women of Valour. Vol. 1 - 3. Lagos: The African Cultural Institute.

Mama, Ayesha. (1989). The Hidden Struggle - Statutory and Voluntary Sector Responses to Violence Against Black
Women in the Home. London Race and Housing Research.

Nwapa, Flora. (1966). Efuru. London: Heinemann.

Okoye, Ifeoma. Behind the Clouds. (1986). London: Longman.

Okoye, Ifeoma. Men Without Ears. (1984). Essex: Longman.

Ogundipe-Leslie, Omolara. (1985). 'The Study of Women through Imaginative Literature', in AAWORD Occasional Paper Series, no. 2, 77-83.

Ogundipe-Leslie, Omolara. (2007). Indigenous and Contemporary Gender Concepts and Issues in Africa. Lagos: Malthouse Press Limited.

Okpewho, Isidore. (1983). Myth in Africa. Cambridge: Cambridge University Press.

Onwueme, Tess. (2000). Shakara: Dance-Hall Queen. New Rochelle, NY: African Heritage Press.

Onwueme, Tess. (1988). The Reign of Wazobia. London: Heinemann Educational Books.

Oyewunmi, Oyeronke. (1997). The Invention of Women. Minneapolis: University of Minnesota.

Oyewunmi, Oyeronke. (Ed.). 2004. African Women and Feminism: Reflecting on the Politics of Sisterhood. N.Y.: African World Press.

Walby, S. (1990). Theorizing Patriarchy. Oxford: Basil Blackwell.

Weinger, Susan; Fonjong, Lotsmart; Fonchingong, Charles and Roberta Allen. (2006). Unmasking Women's Rivalry in Cameroonian Folktales. Nordic Journal of African Studies 15(1): 16-26. 